\title{
前川國男の屋上庭園におけるル・コルビュジエからの受容 \\ THE ACCEPTANCE OF LE CORBUSIER IN KUNIO MAYEKAWA'S ROOF GARDEN
}

\author{
塚 野 路 哉*, 千代 章一郎**
}

\author{
Michiya TSUKANO and Shoichiro SENDAI
}

\begin{abstract}
The influence of Le Corbusier (1887-1965) upon the architectural works of Kunio Mayekawa (1905-1986) is often cited in studies; indeed, Mayekawa himself mentioned that he had been influenced by "Dom-ino (1914)," as Le Corbusier had insisted. This study focuses upon Kunio Mayekawa's roof gardens in his architectural works and analyzes his application of Le Corbusier's roof gardens. As a result, it is shown that Kunio Mayekawa, taking the Villa Savoye (1932) and Unité d'Habitation de Marseille (1952) as references, has accepted Le Corbusier's roof garden into his own architectural works.
\end{abstract}

Keywords : Kunio Mayekawa, Roof Garden, Le Corbusier, Villa Savoye, Unité d'Habitation 前川國男, 屋上庭園, ル・コルビュジエ, サヴオワ邸, ユニテ・ダビタシオン

1. 序

\section{1 . 目的}

前川國男(1905-1986)の建築作品は、しばしばル・コルビュジエ(Le Corbusier, 1887-1965)からの影響が指摘され ${ }^{1,2}$ 、また、前川國男自身 も、設計活動を通してル・コルビュジエが提唱するドミノ(Dom-Ino,

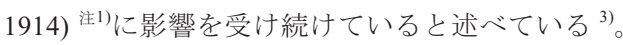

とはいうものの、実際にはドミノを構成原理とする「新しい建築 の $5 つ の$ 要点(Les 5 points d'une architecture nouvelle, 1929)」に関して、 日本の未熟な技術水準や不合理性を理由に断片的な使用に留めてい る 注2)。しかしながら、日本の施工方法や技術でも実現可能な屋上庭 園に限っては、設計活動を通して計画し続けていることに着目した い。

実際、前川國男自身が記した屋上庭園に関する言説はそれほど多 くないものの（表 1)、誌面での発表を目的としていない明治製菓銀 座売店競技設計図集(1931)の説明文を除くと、いずれもル・コルビ ユジエの作品に関する記述であり、前川國男の屋上庭園にはル・コ ルビュジエからの影響が多大にあると推測出来る注31。

ただし、資材不足や施工精度の問題から、屋上庭園の作品数は相 対的に少なく注4)、前川國男の屋上庭園に関する既往研究も多くない 注5)。

しかしかりに前川國男の建築作品における屋上庭園が、戦前・戦 中、戦後を通してル・コルビュジエの手法を実践することができた 唯一の手法であるならば、ル・コルビュジエの建築作品における屋 上庭園からの影響を通時的に明らかにすることで、前川國男の建築 制作論としての新しい知見が得られるものと考える注6)。
表 1 前川國男による屋上庭園に関する言説

\begin{tabular}{|c|c|c|}
\hline 掲載年 & 言説 & 対象作品 \\
\hline 1931 & \begin{tabular}{|l|} 
屋上園:ベビーゴルフ又は喫茶室。ノーマルな形は如何なる途にも融通 \\
自在たらん \\
(前川國男: 計画説明書, 明治製菓銀座売店競技設計図集, 洪洋社, p.1, \\
1931）
\end{tabular} & \begin{tabular}{|c} 
明治製菓銀座 \\
売店, 1931
\end{tabular} \\
\hline 1941 & $\begin{array}{l}\text { 恐らく“鳥の歌声”をとどむるにすら由なきコルビュジエ描くところの“空中 } \\
\text { 園”のささやかな夢さえも一片の反古となり終わる今日、われらは一体何 } \\
\text { に希望をつなき、どこに明日の国土の意匠を試みんとするのであるか } \\
\text { (前川國男:埋もれた伽藍, 新建築, 新建築社, p.134, 1941.4) }\end{array}$ & $\begin{array}{l}\text { ル・コルビュジ } \\
\text { エの作品全般 }\end{array}$ \\
\hline 1947 & 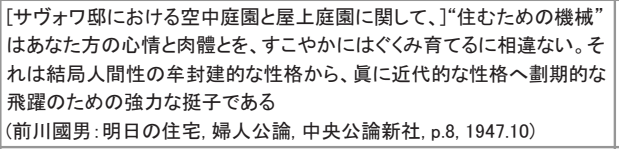 & $\begin{array}{c}\text { Villa Savoye, } \\
1932\end{array}$ \\
\hline 1957 & $\begin{array}{l}\text { わが国の現状は避難通路以外にはあまり利用されていないが、高層に } \\
\text { なると、屋上はは地面にに代わるものとして積極的に共同施設の場所として } \\
\text { 利用されるべきである } \\
\text { (前川國男:新制建築計画, オーム社, pp.117-118, 1957) }\end{array}$ & $\begin{array}{c}\text { Unité } \\
\text { d'Habitation de } \\
\text { Marseille, } 1952\end{array}$ \\
\hline
\end{tabular}

\section{2. 研究方法}

前川國男の建築作品に関する一次資料として、前川建築設計事務 所に保管されている図面資料や言説に加え注7)、前川國男自身の作品 集及び、前川國男建築設計事務所・MID 同人・前川建築設計事務所 の名で建築専門誌に発表された資料を用いる注8)。

一次資料より、前川國男の建築作品における屋上庭園を抽出し注9)、 既往研究に依拠して 4 期に分類することで ${ }^{4}$ 注 10$)$ 、期毎の形態や空 間構成の特徵を把握する ( 2 章)。その上で、前川國男が屋上庭園に 関して言及しているサヴォワ邸(Villa Savoye, 1932)とマルセイユの ユニテ・ダビタシオン(Unité d'Habitation de Marseille, 1952)の 2 作品 を、前川國男自身の素描や写真をもとに再解釈することで、前川國
* 広島大学大学院工学研究科 修士 (工学)

** 広島大学大学院工学研究院 准教授 $\cdot$ 博士 (工学 
表 2 屋上庭園が設けられた前川國男とル・コルビュジエの実施作品

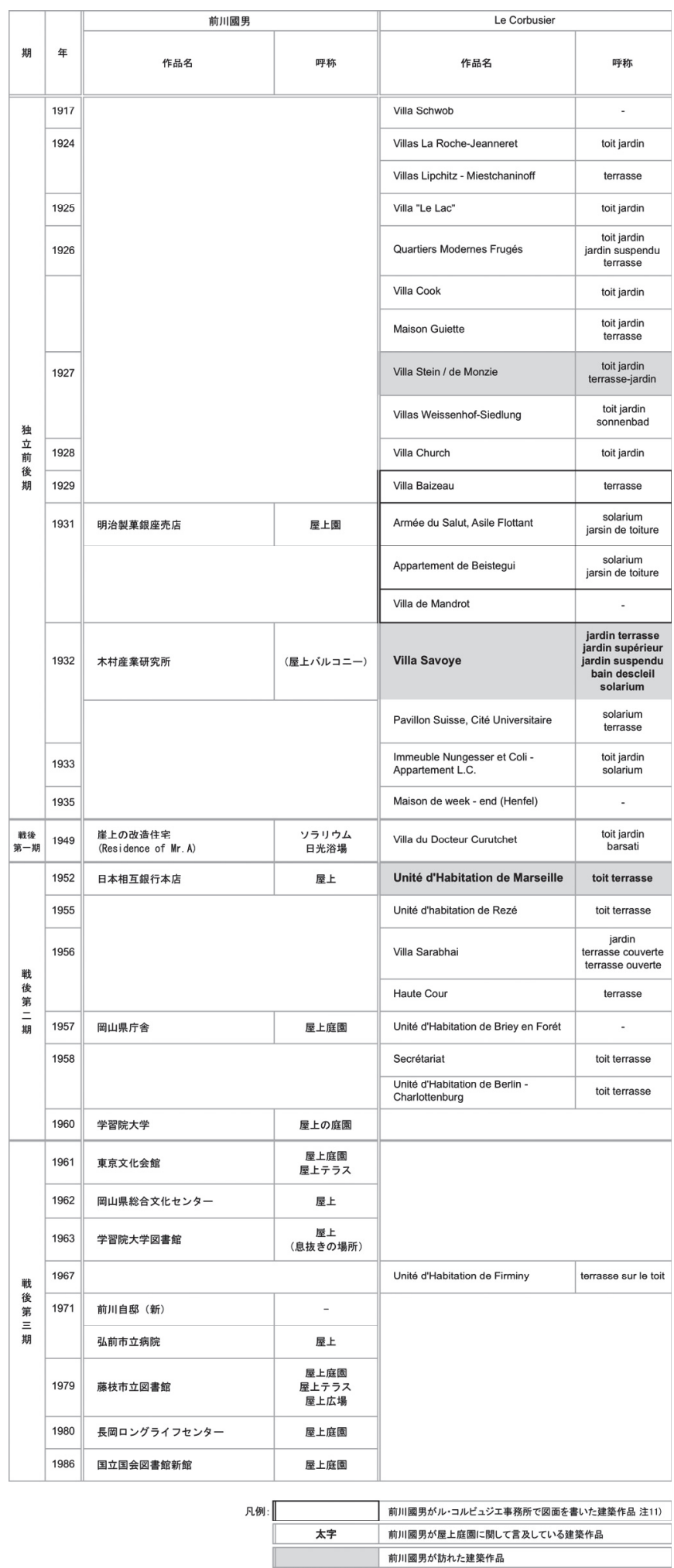

表 3 前川國男の建築作品数及び屋上庭園数

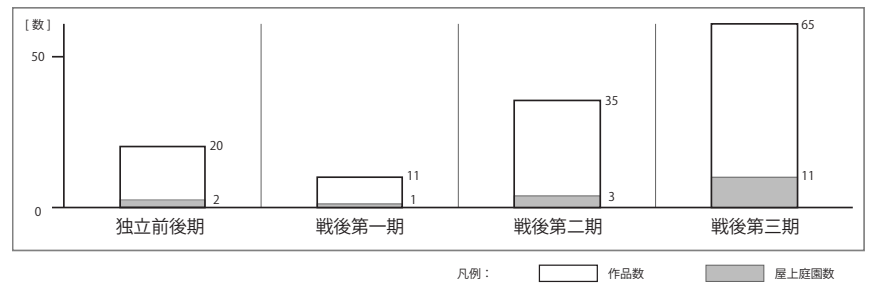

男が屋上庭園のどのような要素に着目しているのかを論じる ( 3 章)。 次に、ル・コルビュジエの屋上庭園に対する前川國男の解釈と、前 川國男自身の屋上庭園における実践との差異や類似性を分析するこ とで ( 4 章)、前川國男の屋上庭園におけるル・コルビュジエからの 受容の变遷を分析する。

\section{3. 既往研究}

前川國男の建築作品に関して、西欧からの影響を指摘した論考は 少なからずある。代表的なものとしては、ル・コルビュジエの建築 作品との形態的な類似性から、両者の影響関係を明らかにしている 分析がある ${ }^{5-8)}$ 。ただし、これらは特定の建築作品を研究対象として おり、また、屋上庭園については言及されていない。なお、屋上庭 園に関する師からの受容という意味では、アントニン・レーモンド (Antonin Raymond, 1888-1976)からの影響も考えられるが、前川國男 はレーモンドが計画した屋上庭園(roof garden)に関しては言及して いないことから注12)、本稿ではル・コルビュジエからの受容に焦点を 当てている。

また、日本近代の屋上庭園に関して、園芸史の観点から主題的に


成との関係性を明らかにした研究があるが ${ }^{13)}$ 、日本国内で計画され た屋上庭園を包括的に扱った研究であり、また、対象年代が異なる 事から、前川國男の建築作品は含まれていない。

\section{2. 前川國男の建築作品における屋上庭園の概要}

\section{表 4 前川國男の建築作品における屋上庭園の概要}

\begin{tabular}{|c|c|c|c|c|c|}
\hline 期 & 建築類型 & 用途 & 躯体構造 & 植栽 & 平面·立面構成 \\
\hline $\begin{array}{l}\text { 独 } \\
\text { 前 }\end{array}$ & $\begin{array}{l}\text { 事務所 } \\
\text { 店舗 }\end{array}$ & 眺望 & $\mathrm{RC}$ & $\times$ & \\
\hline 躈 & 住宅 & $\begin{array}{l}\text { 眺望 } \\
\text { 休息 }\end{array}$ & W & $x$ & \\
\hline 䈅 & $\begin{array}{l}\text { 公共建築 } \\
\text { 事務听 }\end{array}$ & $\begin{array}{l}\text { 避難 } \\
\text { 眺至 }\end{array}$ & $\begin{array}{l}\text { RC } \\
\text { SRC }\end{array}$ & $\Delta$ & \\
\hline 戰 & $\begin{array}{c}\text { 公共建築 } \\
\text { 住宅 }\end{array}$ & $\begin{array}{l}\text { 観賞 } \text { 眺 }^{\text {休 }} \\
\text { 散策 } \\
\text { なよ゙ }\end{array}$ & $\begin{array}{c}\mathrm{S} \\
\mathrm{RC} \\
\mathrm{SRC}\end{array}$ & 0 & \\
\hline
\end{tabular}

前川建築設計事務所の主要建築作品及び竣工時に建築専門誌に発 表した全 131 作品中注 ${ }^{13)}$ 、屋上庭園は 14 作品あり、そのうちの 10 作品に「屋上庭園」もしくはそれに類する呼称が用いられている。 また、屋上庭園の用途が明白であるにも関わらず呼称の示されてい ない作品が 1 作品ある（表 2)。 
独立前後期(1932-1945) に計画された屋上庭園は、小規模の私的用 途に限られ、形態要素の少ない簡素な構成で計画されている。戦後 第一期(1946-1950)になると、次第に造形的な形態要素が配されるよ うになり、長時間の利用が想定される。そして、戦後第二期 (1951-1960)には、次第に大規模の建築に設けられた公共の用途へと 変化し、単一平面に配された形態要素は、より彫塑的となる。さら に、戦後第三期(1961-1986)なると、用途や躯体構造の多様化ととも に形態要素は減少し、植栽や自然素材を多用した段状の構成が用い られている（表 4)。

なお、作品数に対する屋上庭園の割合は、戦後第二期(1951-1960) 以前はさほど変わらないものの、戦後第三期(1961-1986)以降に顕著 に増加している。つまり前川國男は、設計活動を通して屋上庭園に 着眼を置き、技術的に陸屋根や屋上の土壌利用が容易になる設計活 動後期において、より積極的に屋上庭園を計画していることがわか る（表 3）。

3.ル・コルビュジェの屋上庭園に対する前川國男の解釈（表 5) 屋上庭園に関する前川國男の言説は、誌面での発表を目的として いない明治製菓銀座売店競技設計図集(1931)の説明文を除くと、い ずれもル・コルビュジエの作品に関する記述であり（表 1)、特に、 特定の建築作品に関する記述は、前川國男自身が訪れたことのある ル・コルビュジエの屋上庭園について、その建築的効果を肯定的に 捉えている注14)

前川國男は、1957 年の記述において、マルセイユのユニテ・ダビ タシオン(Unité d'Habitation de Marseille, 1952)の屋上庭園(toit jardin, solarium)に着眼を置き、日本の環境にも置換す心゙きと記している。 また、屋上庭園のみに関寸る記述ではないものの、サヴオワ邸(Villa Savoye，1932)における半屋外空間の構成に対して述べた記述の中で、 部分的に屋上庭園に触れている。

表 5 前川國男によるル・コルビュジェの屋上庭園の解釈

\begin{tabular}{|c|c|c|}
\hline 作品名 & Villa Savoye, 1932 & Unité d'Habitation de Marseille, 1952 \\
\hline 前川國男が訪れた年 & 1930 & 1951 \\
\hline \multicolumn{3}{|l|}{ 前川國男の解积 } \\
\hline 著眼点 & 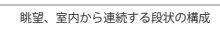 & 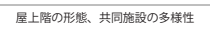 \\
\hline
\end{tabular}

\section{1. サヴォワ邸 (Villa Savoye, 1932)}

420 万戸もの住宅が不足する敗戦後の切迫した状況下において ${ }^{14)}$ 、 前川國男は封建的な家制度を解体し、住宅を近代化することこそが、 新しい時代の生活像を提示できると考え、ル・コルビュジエが提唱 する「住むための機械(machines à habiter)」に着目している（表 1) 注15)。そして、その典型例としてサヴォワ邸(Villa Savoye, 1932)を挙 げ、屋上庭園(jardin suspendu, solarium)を含む半屋外空間の素描を添 えたうえで、ル・コルビュジエが度々言及している衛生機能の主題 を日本に取り入れるべきと記している注16)。

この言説において、前川國男はピクチャーウィンドウを始めとす る形態要素に関しては一切記述しておらず、一見、形態的な特徵に はさほど関心を寄せていない様にも読み取れる。一方、掲載してい
る素描からは（図 1)、屋上庭園単体に着目しているというよりむし ろ、空中庭園と屋上庭園が段状に連続する半屋外空間全体に着眼し、 併せて、屋内居室との視覚的な連続性や、周辺環境への眺望にも関 心を寄せていることがわかる。

以上のような傾向は、前川國男自身が撮影した写真に端的に現れ ている注17)。前川國男が工事中のサヴォワ邸を訪れた際に撮影した写 真は、ピクチャーウィンドウなどの形態的特徴のある構成要素を写 すことなく、上下階がシームレスに繋がる段状の空間構成や、室内 居室との視覚的な連続性が一望できる視点位置から撮影されている (図 2)。

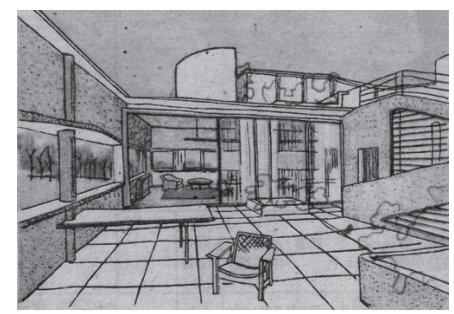

図 1 前川國男によるサヴォワ邸の素描(1947) 注18)



図 2 前川國男が撮影したサヴォワ邸の写真 (1930)

3. 2. マルセイユのユニテ·ダビタシオン(Uni té d' Habitation de Marseille, 1952)

朝鮮戦争を特需とする高度経済成長期に入ると、前川國男は新制 建築計画にマルセイユのユニテ・ダビタシオン(Unité d'Habitation de Marseille, 1952)の屋上庭園に関する概略図と言説を掲載し（表 1）注 19)、高層建築における新たな手法の 1 つとして、多様な共同施設を 包含する屋上庭園(toit jardin)を日本に普遍化させようと試みている (図 3)。

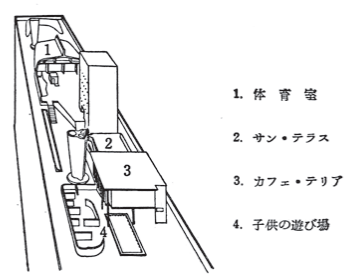

図 3 前川國男によるユニテ・ダビタシオンの概略図 (1957)

なお、概略図には構成要素の彫塑的な形態がくまなく示されてい るのに加え、多数の共同施設の内、「体育館」、「サン・テラス」、「カ フェ・テリア」「子供の遊び場」の 4 施設が凡例で示されている。た だし、本来は「託児所(Garderie d'enfants)」である施設を「カフェ・ テリア」と誤記していることから、前川國男はLe Corbusier\&Pierre

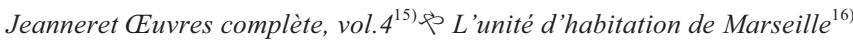
に掲載された図面資料を参照にしつつ、不明箇所を推測しながらこ 
表 6 前川國男の建築作品における屋上庭園

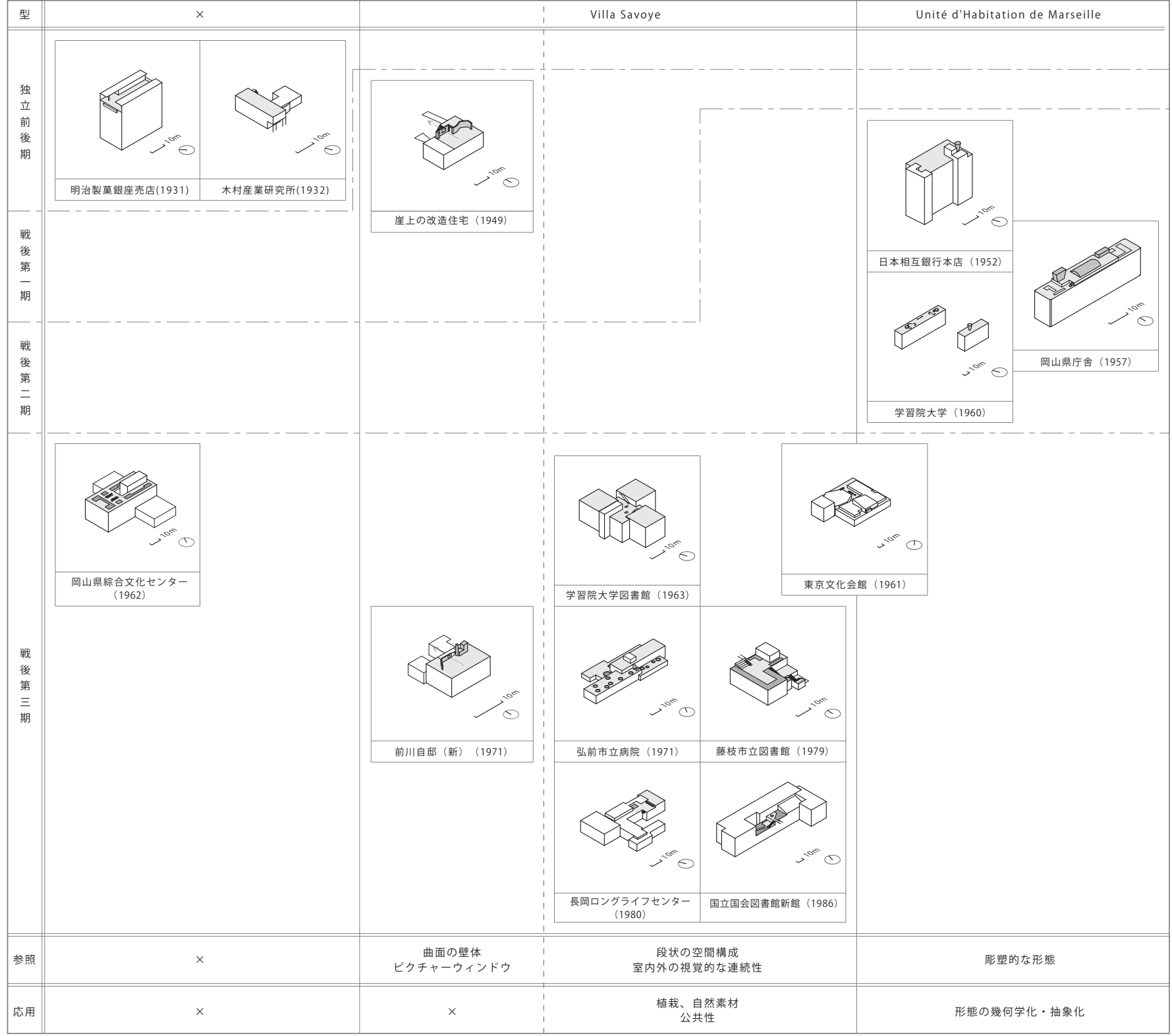

の概略図を素描していると推測出来る注20)。

つまり、前川國男はマルセイユのユニテ・ダビタシオンを訪れな がらも注21)、屋上庭園に配された各公共施設の用途に関しては把握し ておらず、むしろ、単一平面上に配された構成要素の彫塑的形態や 共同施設の多様性に関心を示している。

\section{4. 前川國男の屋上庭園におけるル・コルビュジェからの受容 (表 6)}

\section{1. $1932-1945$ (独立前後期)}

この時期に屋上庭園が計画されたのは、木村産業研究所(1932)と 明治製菓銀座売店(1931)の 2 作品のみであり注22)、いずれも立面構成 に関してガルシュのヴィラ(Le Corbusier: Villa Stein-de Monzie, 1926) やラ・ロッシュ＝ジャンヌレ邸(Le Corbusier: Villas La RocheJeanneret, 1923)からの多大な形態的影響が指摘されている注23)。しか しながら、屋上庭園に限ると直接的な類似性は認められず、参照元 は特定できない（図 4)。
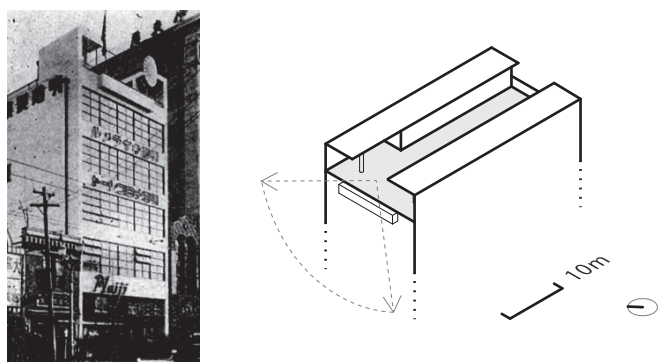

図 4 明治製菓銀座売店 (1931) の屋上庭園

木村産業研究所と明治製菓銀座売店の屋上庭園は、いずれも形態 要素や屋内居室との関係性を極力排した簡素な構成で計画されてい

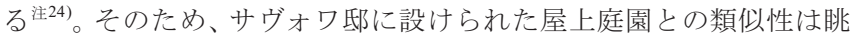
望の有無に限られ、参照元がサヴオワ邸であるとも言い切れない。 つまり、前川國男はル・コルビュジエの立面構成を自らの実作にお いて試みたことで、副次的に屋上庭園を設けているにすぎない。 


\section{2. $1946-1950$ (戦後第一期)}

資材不足のために木造を選択せざるを得ない敗戦後の状況下にお いて、前川國男はほぼ全ての作品を木造の勾配屋根で計画し、屋上 庭園を概㸚用いていない。ただし、崖上の改造住宅(Residence of Mr.A, 1949)には唯一、木造であるにもかかわらず休息や眺望のための屋上 庭園（ソラリウム）を計画し、様々な形態要素を配している。なお、 崖上の改造住宅に限って木造の屋上庭園が計画された要因は、この 計画のみが新築ではなく改修であるためと推測出来る。前川國男は 既存の勾配屋根を補修する代わりに、勾配屋根の上部に歩行可能な デッキを敷き、それを屋上庭園として構成している。つまり、厳密 な雨水処理を必要としない案件に限ってのみ、屋上庭園を試みてい る(図 5)。
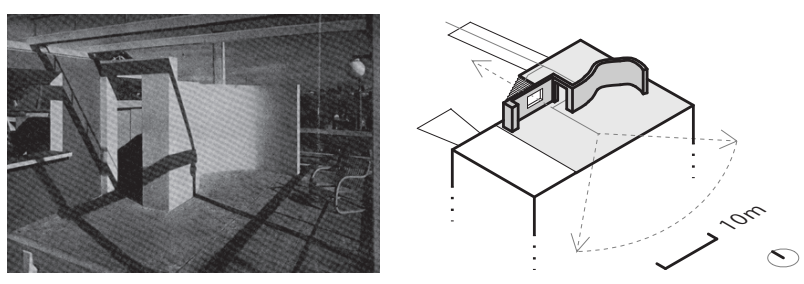

図 5 崖上の改造住宅 (1949) の屋上庭園

前川國男のサヴォア邸に関する記述では、ピクチャーウィンドウ をはじめとする形態要素の記述はなされていないにもかかわらず、 崖上の改造住宅の屋上庭園には、曲面の壁体やピクチャーウィンド ウなど、サヴォワ邸の屋上庭園と類似する形態的特徵が散見でき、 「ソラリウム」の呼称もまた、前川國男がサヴォワ邸の参考資料と していた Le Corbusier \& Pierre Jeanneret Euvres complète, vol.2 の記 述と同様に用いられている。ただし、崖上の改造住宅の屋上庭園に 設けられた曲面の壁体やピクチャーウィンドウは、眼下に豊かな景 観が広がる南側ではなく、住宅が密集する北側に向けて配されてい る。そのため、近隣住民からの視線を調整するための装置として設 けられていると推測でき、景観豊かな敷地に建つサヴォワ邸の手法 とは大きく異なる。

また、前川國男はサヴォワ邸の屋上庭園において、形態的な特徴 よりむしろ、上下階がシームレスに繋がる段状の空間構成や、室内 外の視覚的な連続性に着眼しているのにも関わらず、崖上の改造住 宅は隣地とつながる陸橋が設けられるのみで、屋上庭園そのものは 高低差のない平坦な構成で計画されている。そのため、崖上の改造 住宅の屋上庭園は下層居室との関係性が希薄であり、視覚的にも断 絶されている。

つまり、前川國男はサヴォワ邸の屋上庭園を日本に置換しょうと 試みるものの、漏水の危険性や技術的な懸念を要因として、自身が 着眼していた空間構成を参照することは叶わなかったと推測できる。 一方、ピクチャーウィンドウを始めとする構成要素の形態的特徴に 関しては、近隣住民に対する視線調整という新たな効果を見出した ことで、少なからず用いている。

\section{3. $1951-1960$ (戦後第二期)}

この時期に屋上庭園が計画された作品は、日本相互銀行本店 (1952)及び岡山県庁(1957)、学習院大学(1960)の 3 作品のみであり、 公共建築や大規模な事務所ビルに用いられている。

なお、この時期の計画は、既往研究にてチャンディガール州議事
堂(Le Corbusier: Assemblée, 1955)やスイス学生会館(Le Corbusier: Pavillon Suisse, 1930)、マルセイユのユニテ・ダビタシオンからの形 態的な影響が指摘されているものの主25)、屋上庭園に限ると、この中 で唯一前川國男自身が屋上庭園を訪れたことのあるユニテ・ダビタ シオンからの影響が色濃く現れている。事実、この時期に計画され た屋上庭園はいずれも、矩形の平面構成に逆錐型の給水塔や塔屋、 円弧型の据え置きベンチなどが配され、前川國男がユニテ・ダビタ シオンの屋上庭園において着目していた彫塑的な形態と部分的に類 似している（図 6)。

ただし、前川國男はユニテ・ダビタシオンで着眼した形態要素を そのまま用いるのではなく、ル・コルビュジエが用いた自由曲線を、 単純化・抽象化することで幾分か変形して用いている。
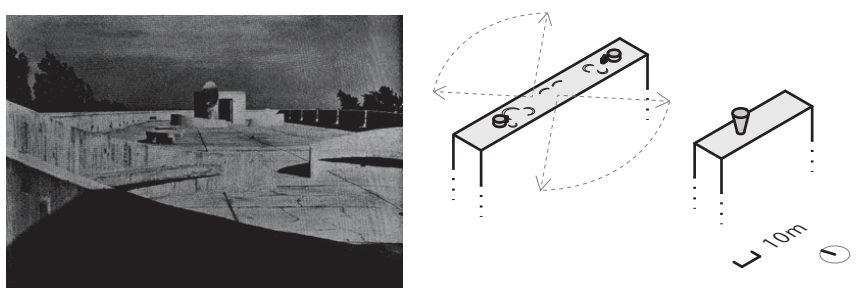

図 6 学習院大学 (1960)の屋上庭園

一方、前川國男はユニテ・ダビタシオンの屋上庭園における共同 施設の多様性にも着眼しているものの、日本の公共施設が従来には 無い機能や用途の提案を受け入れ難いことや注26)、前川國男が避難 の用途に重点を置いていることを要因として、休息・避難以外の用 途や施設を概社計画していない。

4.4.1961-1986（戦後第三期）
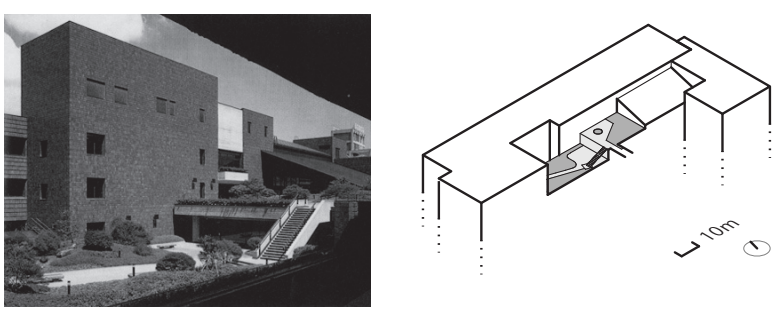

図 7 国立国会図館新館 (1986) の屋上庭園

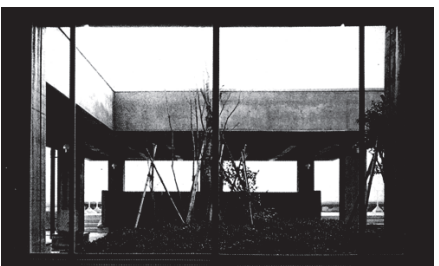

図 8 長岡ロングライフセンター (1980)の屋内から見た屋上庭園

この時期に計画された屋上庭園は 8 作品あり、長岡ロングライフ センター(1980)や国立国会図館新館(1986)を典型として（図 7)、公 共建築に多く用いられている。なお、この時期の屋上庭園の多くは、 複数の庭園が水平・鉛直方向に雁行しながら連続する構成で計画さ れ、前川國男がサヴォワ邸の屋上庭園で着眼していた段状の空間構 成による、屋内居室との視覚的な連続性や周辺環境への眺望が模索 されている（図 8)。 
なお、前川國男がこの時期の屋上庭園に配している形態要素は、 概ね花壇や植栽、可動のベンチに限られている。そのため、前川國 男がサヴオワ邸やマルセイユのユニテ・ダビタシオンの屋上庭園に おける主要な形態的特徴を、自身の屋上庭園に参照しているとは言 (難い注27)。

一方、前川國男自身がル・コルビュジエと日本の自然観に差異が あると記しているように注28)、曲線や起伏を多用した築山や植栽、ま た、自然素材を多用した曲線のペーブメントなど、ル・コルビュジ エとは一線を画した表現を試みている。

つまり、前川國男はサヴォワ邸の屋上庭園で着眼した空間構成を、 規模の大きな公共建築において適用し、サヴオワ邸の形態的な特徵 を極力参照することなく、また、自然素材や植栽を加味することで、 独自の手法として応用していると考えられる。

\section{5. 結}

前川國男の屋上庭園におけるル・コルビュジエからの受容に関し

て、下記のことを明らかにした。

1）前川國男は、設計活動を通してル・コルビュジエが計画する屋上 庭園(toit jardin)に着目し続け、時代毎の社会的な課題に対する解決 策として、日本の環境への置換を模索している。なお、本稿は前 川國男の屋上庭園に影響を与えた建築作品を全て明らかにしたわ けではないが、少なくとも、前川國男は自ら訪れたことのあるサ ヴオワ邸(Villa Savoye, 1932)とマルセイユのユニテ・ダビタシオン (Unité d'Habitation de Marseille, 1952)の 2 作品を、屋上庭園の主な 参照元として用いている。

2) 前川國男の屋上庭園におけるル・コルビュジエからの受容は、第 二次世界大戦以降に顕著に現れる。戦後第一期 $(1946-1950)$ は、 サヴォワ邸の屋上庭園に設けられた構成要素の形態的な特徴を直 接的に参照し、また、戦後第二期（1951－1960）には、ユニテ・ ダビタシオンの屋上庭園に配された有機的な形態を、抽象化・幾 何学化することで、応用している。さらに、戦後第三期 $(1961$ - 1986) には、サヴオワ邸における空中庭園と屋上庭園の関係性を自身の 屋上庭園へと応用寸ることで、公共建築における屋上庭園に、屋 内外の視覚的な連続性や散策動線を付加している。

つまり、前川國男は屋上庭園の制作において、形態参照の有無 を問わず一貫して自身が体験したル・コルビュジエ作品に着眼し 続けているのであるが、設計活動後期になるほどに、形態が主張 寸ることのない空間構成そのものとして忘用するようになってい くのである。建築的空間の一部分である「屋上庭園」への着目と いう点では限定的ではあるが、前川國男の建築制作の変容の一端 を明らかにすることができたと考える。

また、前川國男は屋上庭園を通して受容したル・コルビュジエの 手法を、地上の庭園にも応用していると推測できるが注29)、エスプラ ナードをはじめとする地上の庭園と屋上庭園との相互関係に関して は、今後の課題としたい。さらに、前川國男が示した受容のあり方 は、おそらく大高正人(1923-2010) をはじめとする元事務所所員の 屋上庭園へと受け継がれているとも推測できるが、元事務所所員と の比較分析に関しても、今後の課題としたい注30)。

\section{図版出典}

表 1-6: 筆者作成（[]内は筆者注）

図 1: 前川國男: 明日の住宅, 婦人公論, 中央公論新社, p.8, 1947.10

図 2: 松隈洋: ル・コルビュジェのアトリエで, 建築ジャーナル, p.51, 2012.10 図 3: 前川國男 : 新制建築計画, p.118, 1957

図 4: 生誕 100 年前川國男建築展実行委員会 : 建築家前川國男の仕事, 美術出 版社, p.80, 2006

図 5: 新建築, 新建築社, p. 324, 1949.10

図 6: 近代建築, 近代建築社, p.68,1960.10

図 7: 日経アーキテクチュア, 日経 BP 社, p.190, 1986.10.20

図 8: 近代建築, 近代建築社, p.33,1981.3

\section{参考文献}

1）松隈洋：前川國男 現代との対話, 六耀社, 2006

2）アルフレッド・ロート：前川國男への追悼，追悼前川國男，前川建築設計 事務所, 1987

3）前川國男：ル・コルビュジェの言い遺したこと, 一建築家の信條, 晶文社, 1981

4）前川國男, 宮内嘉久：一建築家の信條, 晶文社, 1981

5）松隈洋：近代建築を記憶する, 建築資料研究社, 2005

6）長谷川堯 : 建築の出自, 鹿島出版会, 2008

7）宮内嘉久：前川國男 賊軍の将, 晶文社, 2005

8）高階秀爾，三宅理一，鈴木博之，太田泰人：ル・コルビュジェと日本，鹿島 出版会, 1999

9）近藤三雄：屋上緑化の本来あるべき姿 より質の充実を, ベース設計資料, No.135 建築編，建設工業調査会, pp.36-40, 2007

10）近藤三雄: わが国における屋上庭園の起源と黎明期における展開にて, 造 園技術報告集(5), pp.200-203, 2009

11）山田宏之：屋上庭園今昔, インタラクション,pp.4-24, 2004

12）日置勝人：我が國の屋上庭園, 造園雑誌 9(1), pp.7-13, 1942

13）四ヶ所高志，横山天心，塩崎太伸，奥山信一：現代日本の建築家による屋 上庭園形式をもつ住宅の設計意図, 日本建築学会計画系論文集, 第 80 巻, 第 718 号, pp.2833-2840, 2015.12

14）小野浩：1940 年代後半の戦災都市における住宅復興：戦後統制下の住空 間の創出と分配, 社會經濟史學 79(2),pp.191-212,2013

15) Le Corbusier, Willy Boesiger, ed.,: Le Corbusier Euvres complètes, vol.4, Les Editions d'Architecture Artem, Zurich, 1977

16) Le Corbusier: L'unité d'habitations de Marseille, Le Point, 1950

注

注1）ル・コルビュジエは、それまでの西欧における伝統的な組積造の建築に 対し、水平スラブと柱、階段による「ドミノ(Dom-Ino, 1914)」の架構を提 唱する事で、間取りと機能を構造から完全に独立させている。

注2）前川國男は、日本において壁面と躯体を離す工法は合理性に欠けるとし て、「自由な平面(plan libre)」と「自由なファサード(façade libre)」の 2 つ の手法を否定的に捉えている(前川國男：文明と建築，建築年鑑，美術出版 社, pp.9-14, 1964)。また、三沢浩は前川國男が技術的な問題から戦前・戦 中期には「水平横長空(La fenetre en longueur)」が実現出来なかったと記し ている (三沢浩 : 建築家前川國男の仕事, 美術出版社, p.70, 2006)。さらに、 「ピロティ(pilotis)」は戦後復興期においては用いられていない。

注3）前川國男がル・コルビュジェに関して言及している言説は 41 あり、設 計活動を通して示されている。代表的なものとしては、ル・コルビュジエ の「輝く都市」を批判しているものや(前川國男：不可分の問題，建築雑誌， pp.26-27, 1937.1)、ル・コルビュジェの人となりを示したものなどがある(前 川國男，藤井正一郎：建築家の思想，建築，青銅社, pp.18-23, 1961.1)。

注4）屋上庭園は、陸屋根の上部を常時歩行可能とする施工が必要であり、勾 配屋根に比べ、技術的懸念や予算的懸念が残る。そのため、全作品数に対 する屋上庭園の作品数は必ずしも多いとは言い難い。事実、木村産業研究 所(1932)の屋上庭園は、竕工直後から凍害を要因とする漏水に悩まされ、 度々の補修や改修を余儀なくされている(松隈洋 : 木村産業研究所の挫折か ら, 建築ジャーナル, pp.50-53, 2013.3)。

注5）唯一、前川國男建築設計事務所の元所員である仲邑孔一が、木村産業研 究所の屋上庭園について竣工当時の様子を書き示している(住宅特集, 新建 築, p.56, 2006.1)。

注6）前川國男の建築作品に着目した既往研究として、建築手法の特徴を分析 
した研究（永田祐三：殉教の前川國男, 前川國男作品集 建築の方法II, 前 川國男作品集刊行会, 宮内嘉久編, 美術出版社, 1990 及び、原広司 : 戦後日本 の近代化と前川國男, 前川國男作品集 建築の方法 II, 前川國男作品集刊行 会, 宮内嘉久編, 美術出版社, 1990）や、前川國男の建築作品における伝統と 近代の葛藤、調和を問題提起しているものがある（平良敬一：前川國男に おける日本的感性, 前川國男作品集 建築の方法 II, 美術出版社, 1990 及び、 大谷幸夫 : 拙を守り真実を求めて, 前川國男作品集 建築の方法 II, 美術出 版社，1990）。これらはいずれも、西欧からの影響や日本近代建築の中にお ける位置付けを明らかにした研究であるが、対象作品を戦前もしくは戦後 期に限定した分析である。

注7）前川建築設計事務所に保管されている 370 作品の図面資料および 354 の 論文や対談を対象として用いている。図面資料はマイクロフィルムや原図 で保管され、各作品ごとに契約図面、実施図面、施工図面、設備図面、竣 工図面などが残されている。なお、筆者は 2010 年 9 月 13 日、2014 年 8 月 15 日、 2015 年 3 月 26 日、 2015 年 10 月 29 日、 2016 年 10 月 12 日の計 5 回、 前川建築設計事務所の橋本功代表へヒアリングを行っている。

注8）前川建築設計事務所に保管されている図面資料に関して、竣工図面のあ るものは竣工図面を、竣工図面のないものは実施図面を用いて抽出を行う。 注9）様式的な定義は曖昧であるものの、屋上庭園とは、一般的に建築に付随 する外部空間である地上の庭園を、建築の最上部の陸屋根に移し替えたも のであり、本稿では、原則として前川國男が図面表記において屋上庭園も しくはそれに類する言葉を使用している屋外空間を研究対象とする。

注10）宮内嘉久は、前川國男に関する包括的な理念や手法の既往研究を多く 残した建築史家であり、一建築家の信條 (前川國男, 宮内嘉久：一建築家の 信條, 晶文社, 1981)において、半世紀にわたる前川國男の設計活動を、考え 方や建築作品の変化が顕著な時期毎に分類している。そのため、前川國男 の建築制作の特徴を把握するためは宮内嘉久の分類が適していると判断し、 本稿は一建築家の信條の分類に依拠している。

注11) PLANS(Fondation Le Corbusier: PLANS, Echelle-1, 2005)の署名に依拠する。 なお、図面には複数の署名が併記されているため、前川國男がどの程度設 計に関わっているかは不明である。

注12）松隈洋によると、むしろレーモンドが前川國男を通してル・コルビュ ジェの手法を受容しようと試みている(松隈洋 : ル・コルビュジェとレーモ ンドの間で, 建築ジャーナル, pp.51-52, 2013.3)。

注13) 建築家前川國男の仕事(美術出版社, pp.287-292, 2006) のリストに依拠 する。ただし、同名称で複数の計画があるもの、もしくは同一敷地内の増 改築は 1 作品として集計している。なお、国際文化会館(1955)に関しては、 屋上庭園が前川國男の意向とは言い難く、リストから除外している(内田祥 士 : 再読/日本のモダンアーキテクチャー, 彰国社, pp.86-94, 1997)。

注14）前川國男は屋上庭園のあるガルシュのヴィラ(Villa Stein / de Monzie, 1927)にも訪れているが、中庭から外観を見た際の印象に関する記述しか残 しておらず、建築内部及び屋上庭園に入っているかは不明である。

注15）この素描と言説は、主婦向けに発行されている一般誌に掲載されたも のであるが、ここで主張されている「近代化された住宅の必要性」の主題 は、以降、前川國男によって度々言及され、弟子の浜口ミホにも受け継が れている(浜口ミホ：日本住宅の封建性，相模書房，1949)。

注16）サヴォワ邸(Villa Savoye, 1932)は前川國男がル・コルビュジェの事務所 に在籍している期間(1928.4.17-1930.4)に着手された計画であり、前川國男 は担当ではないものの、設計が進められていく過程を事務所内でつぶさに 見ている(佐々木宏 : 巨匠へ憧憬, 相模書房, pp.181-182, 2000)。

注17）前川國男が工事中のサヴォワ邸を撮影した写真のうち、前川建築設計 事務所に保管されている写真は図 2 の写真に限られる。そのため、本稿で はこの写真のみから判断している。

注18）前川國男が婦人公論に掲載している屋上庭園の素描は、Le Corbusier \& Pierre Jeanneret Euvres complète, vol.2 に掲載された屋上庭園(solarium, jardin suspendu)の写真と構図が近似し、また植栽の形態や家具配置が類似 している。そのため、前川國男は掲載された 16 枚の写真の中からあえて この写真を選択し、模写を作成したものと推測出来る。

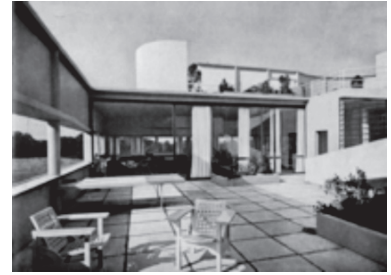

(写真: Le Corbusier, Willy Boesiger, ed.,: Le Corbusier \& Pierre Jeanneret Cuvres complètes, vol.2, Les Editions d'Architecture Artem, Zurich, p.23, 1935)

注19）この文献は技術者や建築の学生に向けて作られた技術指南書であり、 アパートにおける共有部分の項目の 1 つとして屋上庭園が示されている。

注20）ル・コルビュジエが監修した当時の書籍には、屋上庭園に設けられた 公共施設の種類が示されているものの、それぞれの公共施設の位置までは 記されていない ${ }^{15,16) 。}$

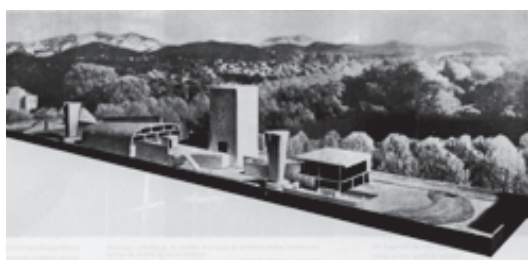

(写真: Le Corbusier, Willy Boesiger, ed.,: Le Corbusier Euvres complètes, vol.4, Les Editions d'Architecture Artem, Zurich, p.185, 1946)

注21）日本代表として CIAM8(1951)に出席した前川國男は、その前後にル・ コルビュジェと供にヨーロッパ各地を周遊している。この旅は記録には残 されていないため、旅行の詳細な行程は不明であるが、前川建築設計事務 所の橋本功氏によると、その間にマルセイユのユニテ・ダビタシオンを訪 れている可能性が高い。

注22）明治製菓銀座売店は、1931 年の設計競技において前川國男が選出され た後、森山松之助建築事務所が前川國男の計画案を踏襲して実施設計を行 うことで、1933 年に施工している。

注23）三沢浩と松隈洋は、木村産業研究所(1932)がガルシュのヴィラ(Villa Stein / de Monzie, 1927)やラ・ロッシュ＝ジャンヌレ邸(Maisons La Roche-Jeanneret, 1929)を参照しているとしている(三沢浩 : 建築家前川國男 の仕事, 美術出版社, p.70, 2006, 及び 松隈洋: 木村産業研究所, 建築文化, pp.186-191, 2000.1)。また、松隈洋は明治製菓銀座売店(1931)がル・コルビ ユジエのデザインを試みたものとしている(松隈洋:建築家前川國男の仕事, 美術出版社, p.80, 2006)。

注24）明治製菓銀座売店競技設計(1931)の一般計画要旨には、「<単純>はく<貧 弱>に非ず。純な<平面>は建築家最大の若闘を秘む」と示されている(前川 國男：計画説明書, 明治製菓銀座売店競技設計図集, 洪洋社, p.1, 1931)。

注25）佐々木宏：巨匠一憧憬，相模書房, p.194, 2000 及び、Roger Sherwood: Harumi Apartment, a+u 臨時増刊号, p.60, 1975.3

注26）前川國男, 浜口隆一, 池辺陽 : 婦人の解放と住宅問題 家事労働を中心 として, 婦人公論, pp.42-48, 1948.12

注27）ル・コルビュジエの他の屋上庭園の形式が参照されていた可能性も否 定できないが、少なくとも明示的な参照はサヴォア邸とユニテ・ダビタシ オンであることは本論での分析の通りである。また、新・前川自邸(1971) の屋上庭園は、例外的にサヴォワ邸に設けられた構成要素との形態的な類 似性が認められる。その要因は、前川國男自身の住宅であり、専門誌への 作品発表を予定していなかったためと推測できる。つまり、前川國男は人 知れず自身の嗜好で屋上庭園を計画する際に限って、ル・コルビュジェが 用いた形態への抗えきれない憧憬を残存させている。

注28）前川國男：解説鼎談, 建築十字軍, 東海大学出版会, p.204, 1978

注29）水平的かつ鉛直的に連続する段状の空間構成は、埼玉会館(1966) の工 スプラナードをはじめとして、前川國男が設計活動後期に計画する地上の 散策路においても同様に用いられている。

注30）坂倉準三(1901-1969)や吉阪隆正(1917-1980)、丹下健三(1913-2005)をは じめとする同時代の建築家が計画した屋上庭園との比較考察も、今後の課 題としたい。 
THE ACCEPTANCE OF LE CORBUSIER IN KUNIO MAYEKAWA'S ROOF GARDEN

\author{
Michiya TSUKANO* and Shoichiro SENDAI** \\ * Graduate School of Engineering, Hiroshima University, M. Eng. \\ ** Assoc. Prof., Institute of Engineering, Hiroshima University, Dr. Eng.
}

The influence of Le Corbusier (1887-1965) upon the architectural works of Kunio Mayekawa (1905-1986) has often been recognized in studies. Moreover, Mayekawa himself mentioned that he had been influenced by "Dom-ino (1914)" as Le Corbusier insisted. Having said that, among the " 5 points of modern architecture (Les 5 points d'une architecture nouvelle, 1929)" reflected in principle by Dom-ino, only the roof garden was continued by Mayekawa throughout his design activities. If the roof garden in Mayekawa Kunio's works is the only method borrowed from Le Corbusier before, during, and after the war, we can obtain a new idea regarding the construction theory of Kunio Mayekawa by clarifying how Le Corbusier influenced his use of this element.

I have used the drawing material and anthologies of Mayekawa Associates Architects \& Engineers as my primary sources concerning the works of Mayekawa. I have considered the roof gardens included in Mayekawa's works from these primary materials, classified them into four periods based on existing studies, and thus understood each outline by period (Chapter 2). Next, I have analyzed the elements of the roof garden, upon which Kunio Mayekawa particularly focused at the influence of Villa Savoye (1932) and Unité d'Habitation de Marseille (1952), based upon the drawings and photographs by Kunio Mayekawa (Chapter 3). In addition, I have analyzed the influence of Le Corbusier upon Mayekawa's roof garden by considering the differences between, and similarity to, Mayekawa's roof garden and his interpretation of that of Le Corbusier (Chapter 4).

As a result, I have clarified the following two aspects of Le Corbusier's influence upon Mayekawa's roof garden.

1. Mayekawa continued to focus upon Le Corbusier's roof garden in his works and used those designs in Japan as a solution to the problems faced by society. In fact, Mayekawa's roof gardens have been compared to the works of Le Corbusier, each of which Mayekawa had visited. Mayekawa's roof garden can be explained by its relation to the Villa Savoye (1932) or Unité d'Habitation de Marseille (1952).

2. Kunio Mayekawa's acceptance of Le Corbusier's roof garden showed particularly after World War II. In the first period after the war, Mayekawa referred to the style of the composition's elements established in the roof garden of Villa Savoye directly. In the second period after the war, he applied the organic style of the composition elements arranged in the roof garden of Unité d'Habitation de Marseille by abstracting it and making it geometric. In the third period after the war, by applying the relation between a hanging garden and a roof garden at the Villa Savoye to his own roof garden, he added visual indoor-outdoor continuity, as well as a strolling pathway to a roof garden in public buildings. Therefore, Kunio Mayekawa kept his eye upon Le Corbusier's work (which he experienced himself) in the creation of his roof gardens, regardless of whether he referred to their shape. Moreover, Kunio Mayekawa applied the elements that referenced spatial composition rather than referencing forms as he entered the late stage of his career. 